\title{
A Post-Transcriptional Regulatory Mechanism Restricts Expression of the Paraneoplastic Cerebellar Degeneration Antigen cdr2 to Immune Privileged Tissues
}

\author{
John P. Corradi, ${ }^{1}$ Chingwen Yang, ${ }^{1}$ Jennifer C. Darnell, ${ }^{1}$ Josep Dalmau, ${ }^{2}$ and Robert B. Darnell ${ }^{1,2}$ \\ ${ }^{1}$ Laboratory of Molecular Neuro-Oncology, The Rockefeller University, New York, New York 10021, and 2Department of \\ Neurology and the Cotzias Laboratory of Neuro-Oncology, Memorial Sloan-Kettering Cancer Center, New York, \\ New York 10021
}

\begin{abstract}
Paraneoplastic cerebellar degeneration (PCD) is believed to be an autoimmune disorder initiated by the ectopic expression of a neuron-specific protein in breast and ovarian tumors. PCD antisera was used previously to identify several cerebellar degeneration-related (cdr) genes encoding putative PCD antigens. We have found that the cdr2 gene, which encodes a cytoplasmic leucine zipper protein of unknown function, is expressed in PCD-associated tumors, whereas other cdr genes are not; thus, cdr2 encodes the PCD tumor antigen. To determine whether the expression pattern of cdr2 is consistent with its proposed role in PCD, we have isolated the mouse homolog and examined both the mRNA and protein distribution in adult tissues. We have found that cdr2 mRNA is expressed in almost
\end{abstract}

all tissues, whereas the protein is expressed only in the brain and testis. Within the brain, both the cdr2 mRNA and immunoreactivity are confined primarily to neurons in the cerebellum and brainstem, the regions most affected in PCD. These results suggest first that the tissue-specific expression of cdr2 is regulated at a post-transcriptional level. Moreover, because the brain and testis are considered to be immune-privileged sites, the expression pattern of cdr2 is compatible with the autoimmune model of PCD pathogenesis.

Key words: paraneoplastic neurological disease; neuronspecific gene expression; translational regulation; immune privilege; cerebellar degeneration; leucine zipper protein
The paraneoplastic neurological disorders (PNDs) are a rare group of neuronal degenerations that develop as remote effects of systemic malignancies (for review, see Posner and Furneaux, 1990; Darnell, 1996). It is believed that the PNDs are immunemediated, arising when systemic tumors express proteins (called onconeural antigens) that are normally entirely restricted in their expression to immune-privileged neurons. The serum and CSF of PND patients harbor high titers of anti-neuronal autoantibodies that are also reactive with their tumors (Anderson et al., 1988a; Furneaux et al., 1990; Luque et al., 1991). Characterization of the nature of the disorders and the onconeural antigens has been advanced by the use of PND antisera to clone cDNAs encoding the antigens. Studies of several onconeural antigens, including the breast tumor antigen Nova (Buckanovich et al., 1993, 1995) and the small cell lung cancer antigen Hu (Szabo et al., 1991; Dalmau et al., 1992), have demonstrated that the normal expression of their mRNA and protein is neuron-specific. Taken together with evidence that immunity to PND antigens correlates with effective anti-tumor immunity (Dalmau et al., 1990; Darnell and DeAngelis, 1993; Darnell, 1996), these observations suggest a model for PND in which the expression of onconeural antigens in tumor

Received Aug. 23, 1996; revised Nov. 11, 1996; accepted Dec. 4, 1996.

This work was supported by Department of Defense Breast Cancer Research Award DAMD017-94-J-4277 (R.B.D. and J.C.D.). J.P.C. was supported by National Research Service Award Training Grant GM07982-12, and C.Y. was supported by the Cancer Research Institute Oliver R. Grace Endowed Fellowship. We thank J. Okano for assistance with in situ hybridization and members of the Darnell laboratory and Jerome Posner for critical reading of this manuscript.

Correspondence should be addressed to Dr. Robert B. Darnell, Laboratory of Molecular Neuro-Oncology, The Rockefeller University, 1230 York Avenue, New York, NY 10021.

Copyright (C) 1997 Society for Neuroscience $0270-6474 / 97 / 171406-10 \$ 05.00 / 0$ cells initiates an appropriate immune response that subsequently develops into autoimmune neurological disease.

Paraneoplastic cerebellar degeneration (PCD) is a PND that develops in patients with breast and ovarian tumors and is characterized by the presence of a specific autoantibody referred to as "anti-Yo" (Anderson et al., 1988b). Immunohistochemical studies with this antibody reveal that it reacts with both PCD-associated tumor cells (Furneaux et al., 1990) and discrete populations of neurons, reacting most strongly with cerebellar Purkinje cell cytoplasm (Cunningham et al., 1986). PCD antisera identify a major antigen reported as either 52 kDa (Tsukamoto et al., 1989; Sakai et al., 1991) or $62 \mathrm{kDa}$ (Cunningham et al., 1986) and a minor antigen of $34 \mathrm{kDa}$ when used in Western blot analysis of Purkinje cell extracts; the larger molecular weight antigen is readily detectable in PCD tumor extracts (Furneaux et al., 1990).

Using PCD antisera, cDNAs encoding three cerebellar degeneration related antigens (cdr1-3) have been identified. cdr1 encodes the $34 \mathrm{kDa}$ protein, the predicted amino acid sequence of which reveals an unusual structure composed of nearly identical hexapeptide repeats making up 91\% of the protein (Dropcho et al., 1987). cdr2 was cloned independently from both HeLa cell and human cerebellar cDNA libraries (Fathallah-Shaykh et al., 1991; Sakai et al., 1991). This cDNA encodes a protein with a coiled coil/leucine zipper domain present near the N-terminus. A third cDNA (cdr3) cloned from an HeLa expression library (FathallahShaykh et al., unpublished observations), GenBank accession L02867, shares significant homology ( $\sim 45 \%$ predicted amino acid identity) with cdr2, but has not been investigated further.

It has been suggested that cdr2 may be widely expressed in normal tissues, which is problematic for its proposed role in the pathogenesis of PCD. Widespread expression of cdr2 would also 
be inconsistent with the clinical features of PCD, which are restricted to evidence of anti-tumor immunity and neuronal (primarily cerebellar) dysfunction (Peterson et al., 1992). Early studies using PCD antisera found immunoreactivity with cerebellar Purkinje cells when the antibody was used at limiting dilutions (Jaeckle et al., 1985). Subsequent reports have found Purkinje cell immunoreactivity at limiting antibody dilutions, but more widespread reactivity both within and outside the nervous system using high concentrations of antibody (Altermatt et al., 1991; Tomimoto et al., 1993). Furthermore, Sakai et al. (1991) detected the cdr2 mRNA in cerebellum, brainstem, and intestine by reverse transcription PCR (RT-PCR); additional samples were negative but were not controlled for integrity of the RNA.

The present study was undertaken to clarify the expression pattern of the PCD antigen. We have examined three clinical tumors for the expression of cdr genes and found that the cdr2 gene encodes the PCD tumor antigen. We then defined the tissue distribution of the cdr2 mRNA and immunoreactive protein in the adult mouse and have found that expression of the PCD antigen is restricted to the brain and testis, tissues that are recognized as sites of immunological privilege. These results demonstrate that the expression pattern of the PCD antigen is consistent with the proposed autoimmune model of PCD. Interestingly, the cdr2 mRNA displays a wider distribution than the protein, indicating that expression of the cdr2 antigen is regulated at a posttranscriptional level.

\section{MATERIALS AND METHODS}

Tumor RNA extraction and RT-PCR. Frozen samples of ovarian tumors removed from patients with Yo-positive $\mathrm{PCD}$ were obtained from the Memorial Sloan Kettering Cancer Center. Fragments $(100 \mathrm{mg})$ were used for purification of either total or poly $\left(\mathrm{A}^{+}\right)$RNA. Total RNA was prepared by the method of Chomcynski and Sacchi (1987), and the samples were subsequently treated with RQ1 RNase-free DNase (Promega, Madison, WI) before RT-PCR analysis. For the purification of poly $\left(\mathrm{A}^{+}\right)$ RNA, the section was homogenized by sonication in $400 \mu$ l extraction buffer (4 M guanidinium thiocyanate, $0.1 \mathrm{~m}$ Tris- $\mathrm{HCl}, \mathrm{pH} 8.0,1 \%$ dithiothreitol, $0.5 \%$ lauryl sarcosinate), and $800 \mu \mathrm{l}$ of binding buffer $(0.1 \mathrm{M}$ Tris-HCl, $\mathrm{pH}$ 8.0, $0.4 \mathrm{~m} \mathrm{LiCl}, 20 \mathrm{~mm}$ EDTA) was added and the lysate clarified by centrifugation at $18,000 \times g$ for $5 \mathrm{~min}$. Magnetic Dynabeads Oligo (dT) ${ }_{25}$ (Dynal, Great Neck, NY) were prepared by washing $300 \mu \mathrm{l}$ of beads once with $200 \mu \mathrm{l}$ binding buffer. The lysate supernatant was added to the Dynabeads, mixed, and incubated at room temperature for 3-5 min. A magnet was used to immobilize the beads, the supernatant was removed, and the beads were washed three times with $0.5 \mathrm{ml}$ wash buffer (10 mm Tris-HCl, pH 8.0, 0.15 M LiCl, 1 mm EDTA). Poly(A $\left.{ }^{+}\right)$RNA was then eluted in $20 \mu \mathrm{l} 2 \mathrm{~mm}$ EDTA, pH 8.0, at $65^{\circ} \mathrm{C}$ for $2 \mathrm{~min}$.

For RT-PCR reactions, $2 \mu \mathrm{l}$ tumor poly( $\left(\mathrm{A}^{+}\right) \mathrm{RNA}, 1-2 \mu \mathrm{g}$ total tumor RNA, or 20 ng poly $\left(\mathrm{A}^{+}\right)$RNA from normal tissues (CLONTECH Laboratories, Palo Alto, CA) was denatured at $70^{\circ} \mathrm{C}$ for $10 \mathrm{~min}$ and placed on ice. The RNA was reverse-transcribed using random hexanucleotide primers (Boehringer Mannheim, Indianapolis, IN) and Superscript reverse transcriptase (Life Technologies, Gaithersburg, MD) at $42^{\circ} \mathrm{C}$ for 50 min and the reaction stopped by incubation at $95^{\circ} \mathrm{C}$ for $5 \mathrm{~min}$. One-tenth of the first strand cDNA sample was used as template for a PCR reaction using Amplitaq polymerase (Perkin-Elmer, Norwalk, CT) and the following forward and reverse oligonucleotide primers corresponding to $\mathrm{cdr} 2$ : 5'-TGAATGGAGTTGAGA AGCTGGTG-3' and 5'-GAGATGCCCCTCTGTTTCACAG-3'; and cdr3: 5'-CATTGAGCGCCTCCAGGCT-3' and 5'-AGCTCCTTGAGG CAGGGGAA-3'. The product was amplified for 35 cycles $\left(94^{\circ} \mathrm{C}\right.$ for $30 \mathrm{sec}, 55^{\circ} \mathrm{C}$ for $30 \mathrm{sec}, 72^{\circ} \mathrm{C}$ for $\left.1 \mathrm{~min}\right)$. PCR products were labeled by addition of trace amounts of $\left[\alpha^{32} \mathrm{P}\right] \mathrm{dCTP}$ (Amersham Life Science, Arlington Heights, IL) to the reaction mixtures and loaded on a $10 \%$ nondenaturing acrylamide gel and visualized by autoradiography.

cDNA library screening and sequencing. Adult mouse brain and spleen cDNA libraries (Stratagene, La Jolla, CA) were plated at a density of $1 \times$ $10^{5}$ pfu per $135 \mathrm{~mm}$ dish. Plaques were lifted onto nitrocellulose filters for hybridization with ${ }^{32} \mathrm{P}$-labeled probes (Sambrook et al., 1989). The mouse brain library $\left(1.2 \times 10^{6} \mathrm{pfu}\right)$ was screened at low stringency with a probe corresponding to bp 1-872 of the human cdr2 cDNA (Fathallah-Shaykh et al., 1991). This screen resulted in the isolation of a single $2.4 \mathrm{~kb}$ clone. The mouse spleen library $\left(6 \times 10^{5} \mathrm{pfu}\right)$ was screened with a cDNA probe corresponding to bp 153-720 of the mouse brain cdr2 cDNA (see Fig. 2). This screen resulted in the isolation of three overlapping clones, one comprising the full coding regions and untranslated regions (UTR). The cDNA clones were sequenced by the dideoxy method of Sanger et al. (1977) using Sequenase 2.0 (United States Biochemical, Cleveland, OH), and sequence data were analyzed using the MacVector software package (International Biotechnologies, New Haven, CT).

Northern blot analysis. Adult ICR (Charles River) mouse organs were dissected, and total RNA was prepared using the TRIZOL Reagent (Life Technologies) and the protocol recommended by the manufacturer. Total RNA $(30 \mu \mathrm{g})$ was resolved on an agarose $/ 50 \%$ glyoxal gel (Sambrook et al., 1989) and transferred to Biodyne B nylon membrane (Pall, Glen Cove, NY). The RNA was UV cross-linked to the membrane, and the blot was prehybridized in $6 \times$ SSC, $0.5 \%$ SDS, $5 \times$ Denhardt's solution, $0.05 \%$ sodium pyrophosphate, $100 \mu \mathrm{g} / \mathrm{ml}$ denatured herring sperm DNA for $30 \mathrm{~min}$ at room temperature. cDNAs corresponding to a $580 \mathrm{bp}$ fragment of the mouse cdr2 $3^{\prime}$-UTR and the full-length GAPDH coding region were labeled with $\left[{ }^{32} \mathrm{P}\right] \mathrm{dCTP}$ using the Prime-It Kit (Stratagene). The RNA blot was hybridized with $1 \times 10^{6} \mathrm{cpm} / \mathrm{ml}$ labeled probe in $6 \times$ SSC, $1 \times$ Denhardt's solution, $0.05 \%$ sodium pyrophosphate, $100 \mu \mathrm{g} / \mathrm{ml}$ yeast tRNA for $16 \mathrm{hr}$ at $65^{\circ} \mathrm{C}$. The membrane was then washed twice in $2 \times \mathrm{SSC}, 0.1 \%$ SDS, $0.1 \%$ sodium pyrophosphate at $65^{\circ} \mathrm{C}$, and twice in $0.1 \times$ SSC, $0.1 \%$ SDS, $0.1 \%$ sodium pyrophosphate at room temperature, and hybridization was visualized by autoradiography.

Antibody affinity purification and Western blot analysis. The region coding for amino acids 16-192 of human cdr2 was fused in frame to glutathione-S-transferase (GST) in the GSTag vector (the gift of David Ron, New York University). Bacteria transformed with the GSTag-cdr2 plasmid were grown to an $O D_{600}$ of 0.5 and $1 \mathrm{~mm}$ isopropyl thiogalactoside added for an additional $3 \mathrm{hr}$. Cells were harvested and resuspended in ice-cold PBS and lysed by sonication, and the lysate cleared by centrifugation. The cleared lysate was incubated with glutathione Sepharose (Pharmacia Biotech, Piscataway, NJ) and washed in PBS, and fusion protein eluted with $10 \mathrm{~mm}$ reduced glutathione. Purity and immunoreactivity of the GST-cdr2 fusion protein were verified by SDS-PAGE, Coomassie blue staining, and Western blot analysis.

For affinity purification of PCD antisera, Immobilon membrane (Millipore, Bedford, MA) was wetted with methanol and rinsed well with $\mathrm{ddH}_{2} \mathrm{O}$. GST-cdr2 fusion protein $(20-30 \mu \mathrm{g})$ was spotted on a $0.5 \times 3 \mathrm{~cm}$ strip of membrane and blocked for $60 \mathrm{~min}$ in $25 \mathrm{~mm}$ Tris-HCl, pH 8.0, 20 $\mathrm{mm} \mathrm{NaN}_{3}, 150 \mathrm{~mm} \mathrm{NaCl}, 5 \%$ nonfat dry milk. The strip was washed with PBS $/ 0.02 \%$ sodium azide and incubated with $1 \mathrm{ml}$ of PCD antiserum for $2 \mathrm{hr}$ at $4^{\circ} \mathrm{C}$. The strip was then washed four times with $25 \mathrm{~mm}$ Tris- $\mathrm{HCl}$, pH 8.0, $20 \mathrm{~mm} \mathrm{NaN}_{3}, 150 \mathrm{~mm} \mathrm{NaCl}, 0.1 \%$ Triton X-100, two times with $25 \mathrm{~mm}$ Tris- $\mathrm{HCl}, \mathrm{pH} 8.0,20 \mathrm{~mm} \mathrm{NaN}_{3}, 150 \mathrm{~mm} \mathrm{NaCl}, 2$ mM EDTA, and antibody was eluted with $1 \mathrm{ml} 0.2 \mathrm{M}$ glycine, $\mathrm{pH}$ 3.0. The elution was repeated, and the pooled eluates were neutralized with $0.5 \mathrm{~N} \mathrm{NaOH}$ to a final $\mathrm{pH}$ of 7.5-8.0. Ultrafiltration in a Centricon-10 unit (Amicon, Beverly, MA) was used to remove the glycine from the affinity-purified antibody.

For Western blot analysis, the indicated tissues were dissected from adult ICR mice and homogenized in PBS, $2 \times$ SDS sample buffer added, and the samples boiled. Frozen sections of PCD ovarian tumors were pulverized with a mortar and pestle under liquid nitrogen and homogenized in lysis buffer $\left(10 \mathrm{~mm}\right.$ Tris- $\mathrm{HCl}, \mathrm{pH} 7.4,50 \mathrm{mM} \mathrm{NaH}_{2} \mathrm{PO}_{4}, 50 \mathrm{~mm}$ potassium fluoride, $1 \% \mathrm{NP}-40,5 \mathrm{~mm}$ EDTA). Total protein $(45 \mu \mathrm{g})$ from each tissue extract was resolved by $10 \%$ SDS-PAGE and transferred to nitrocellulose membrane. Blots were incubated with affinity-purified PCD antibody diluted to 1:50 or native PCD antisera diluted to 1:400, washed, and incubated with anti-human $\operatorname{IgG}$ conjugated to horseradish peroxidase (Amersham) at a 1:5000 dilution. Reactive proteins were detected using the ECL kit (Amersham) according to the manufacturer's instructions and stripped of antibody according to the ECL protocol.

Two-dimensional (2-D) gel electrophoresis. Cerebellum and testis from $\mathrm{Sm} / \mathrm{Ckc}$ mice were homogenized in 2-D lysis buffer [9.5 M urea, 2\% NP-40, 5\% $\beta$-mercaptoethanol, 2\% Biolyte ampholytes (BioRad Labs, Hercules, CA) consisting of 75\% 3/5 range and 25\% 3/10 range Biolytes]. The lysate was clarified by centrifugation at $2100 \times g$ for $5 \mathrm{~min}$, and protein concentrations were adjusted with 2-D lysis buffer. Isoelectric focusing (IEF) gels were performed essentially by the method of O'Farrell (1975). IEF slab gels [0.75 mm; $9.2 \mathrm{~m}$ urea, $4 \%$ acrylamide (ReadySol IEF, Pharmacia Biotech), 2\% NP-40, and 5\% Biolyte am- 
pholytes] were loaded with $40 \mu \mathrm{g}$ of total protein per lane, and the samples were covered with sample overlay buffer (7\% urea, $2.5 \%$ ampholytes, $5 \% \beta$-mercaptoethanol). The gels were run using $0.01 \mathrm{M} \mathrm{H}_{3} \mathrm{PO}_{4}$ and $0.02 \mathrm{M} \mathrm{NaOH}$ buffers, as described by O'Farrell (1975) at $4 \mathrm{~W}$ constant power. Voltage was limited to $700 \mathrm{~V}$, and gels were run for 1800 $\mathrm{V} / \mathrm{hr}$. Lanes containing the samples were cut from the gel, equilibrated with $1 \times$ SDS sample buffer for $5 \mathrm{~min}$, and loaded horizontally onto a 1 mm $9 \%$ SDS-PAGE gel with a $3 \%$ stacking gel. A single well was loaded with $40 \mu \mathrm{g}$ protein extract in SDS sample buffer for one-dimensional analysis. Gels were transferred to nitrocellulose and probed with PCD antisera.

In situ hybridization. The protocol used was essentially the same as that described by Newman et al. (1995). Adult ICR mouse tissues were embedded and frozen in O.C.T. compound (Miles, Elkhart, IN). Sections $(10 \mu \mathrm{m})$ were cut using a cryostat and applied to Probe-On Plus slides (Fisher Scientific, Pittsburgh, PA). A plasmid containing the same region of the 3'-UTR of the mouse cdr2 gene as that used for the Northern blot was linearized and both sense and antisense riboprobes transcribed using T7 RNA polymerase (Stratagene) and $\left[{ }^{33} \mathrm{P}\right] \mathrm{UTP}$ (Dupont NEN, Boston, MA). Probe was purified on a Sepharose G50 column and hybridized to tissue sections at $50^{\circ} \mathrm{C}$ for $36-48 \mathrm{hr}$.

Immunohistochemistry. For the human tissues, IgG from PCD and normal human sera was isolated and biotinylated, as described previously (Furneaux et al., 1990). Paraffin-embedded sections of ovarian tumor and cerebellum from PCD patients were reacted with the biotinylated antibodies, as described by Verschuuren et al. (1996).

For the mouse tissues, whole organs were dissected from adult ICR mice and tissues were embedded and frozen in O.C.T. compound. Sections $(10 \mu \mathrm{m})$ were fixed in methanol $/ 0.3 \% \mathrm{H}_{2} \mathrm{O}_{2}$ at room temperature for 30-60 min to quench endogenous peroxidase activity, washed in PBS, and blocked with PBS/2\% normal goat serum (NGS) at room temperature for $1 \mathrm{hr}$. Sections were incubated with primary antibody diluted in $\mathrm{PBS} / 2 \% \mathrm{NGS}$ at $4^{\circ} \mathrm{C}$ overnight, washed in PBS, and incubated with biotinylated anti-human $\mathrm{IgG}$ (Vector Laboratories, Burlingame, CA) diluted 1:5000 in PBS/2\% NGS at room temperature for $1-2 \mathrm{hr}$. The signal was enhanced by addition of an avidin-biotin complex (Vectastain Elite Kit, Vector Laboratories) and visualized with diaminobenzidene in the presence of $\mathrm{H}_{2} \mathrm{O}_{2}$.

\section{RESULTS}

\section{Detection of cdr2 message in PCD-associated ovarian tumors}

Previous studies demonstrated that $\mathrm{PCD}$ antisera recognized a protein of $\sim 62 \mathrm{kDa}$ in all PCD tumor samples examined but detected the $34 \mathrm{kDa}$ species (cdr1) in only one (Furneaux et al., 1990), suggesting that cdr2 might encode the PCD tumor antigen. However, the antigenic epitope in cdr2 localizes to the leucine zipper domain of the protein (Sakai et al., 1993), which is nearly identical in sequence to the leucine zipper of cdr3, and both cDNAs were cloned using PCD antisera. To address which of these two genes encodes the in vivo PCD tumor antigen, we assayed PCD tumors for the presence of cdr gene transcripts by RT-PCR. Single-strand cDNA was synthesized from poly $\left(\mathrm{A}^{+}\right)$or total RNA isolated from three ovarian tumors obtained from PCD patients and amplified using gene-specific primers corresponding to cdr2 or cdr3 (Fig. 1). Although both cdr transcripts could be detected in the cerebellum, only cdr2 mRNA was found in the PCD ovarian tumors. In addition, cdr1 mRNA was detected in cerebellum but could not be detected in the PCD tumors (data not shown).

To confirm that the cdr2-positive PCD tumors we assayed came from typical PCD patients, we examined tumor tissue for immunoreactivity with PCD antisera. Figure 2 demonstrates that tumor tissue from one patient (tumor 2) was immunoreactive with PCD antisera (Fig. $2 B$ ) but not control antisera (Fig. 2A); similar results were found with tumors 1 and 2 (data not shown). In addition, we assayed tissue from tumor 3 for PCD reactivity by Western blot analysis. Figure $2 C$ demonstrates that PCD antisera recognized a protein that comigrates with the $\mathrm{PCD}$ antigen rec-

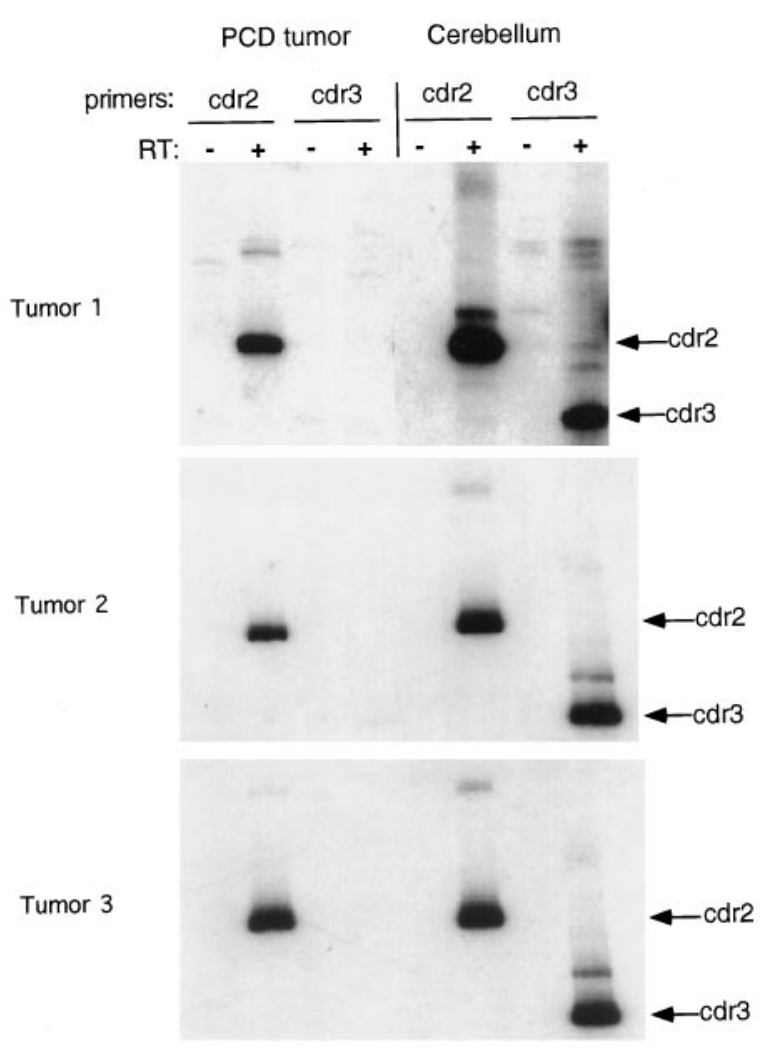

Figure 1. RT-PCR analysis of PCD-associated ovarian tumors. Total or poly $\left(\mathrm{A}^{+}\right)$RNA purified from tumor tissue or human cerebellar poly $\left(\mathrm{A}^{+}\right)$ RNA was used as templates for the RT. Gene-specific primers corresponding to the coding region of either cdr2 or cdr3 were used for PCR amplification of the first strand cDNA. Reactions were performed both in the presence and absence of RT to control for DNA contamination. A $\beta$-actin primer pair was also used as a control for RNA integrity (data not shown). Although the transcripts of the expected size for both cdr2 and cdr3 were detectable in human cerebellum, only the cdr2 transcript was detected in the PCD tumors.

ognized in human Purkinje extracts. Finally, we examined cerebellar tissue obtained from the autopsy of patient 3. Immunohistochemical analysis of cerebellar tissue using PCD antisera revealed the complete absence of immunoreactivity and Purkinje neurons in PCD cerebellum (Fig. $3 A$ ) but showed a characteristic staining pattern in Purkinje neurons of control cerebellum (Fig. $3 B)$. We conclude from the RT-PCR and protein studies that the PCD tumor antigen is the cdr2 gene product.

To facilitate the study of cdr2 expression, we used a human cdr2 cDNA clone (Fathallah-Shaykh et al., 1991) to isolate a $2.4 \mathrm{~kb}$ cDNA encoding cdr2 from an adult mouse brain library (Fig. 4). Because the initiating methionine of the human cDNA has not been defined (Fathallah-Shaykh et al., 1991; Sakai et al., 1991), we compared the degree of nucleic acid homology between the murine and human cdr2 sequences. The sequence homology decreases dramatically immediately upstream of a methionine codon at position 154, and there is an in-frame stop codon at position 88 , indicating that this ATG is the initiation codon. The full-length murine cdr2 open reading frame encodes a protein of predicted molecular weight $52 \mathrm{kDa}$, and its amino acid sequence is $87 \%$ identical to its human homolog (Fig. 4). Within the region of the antigenic epitope (the leucine zipper domain), the mouse and human proteins are identical. 

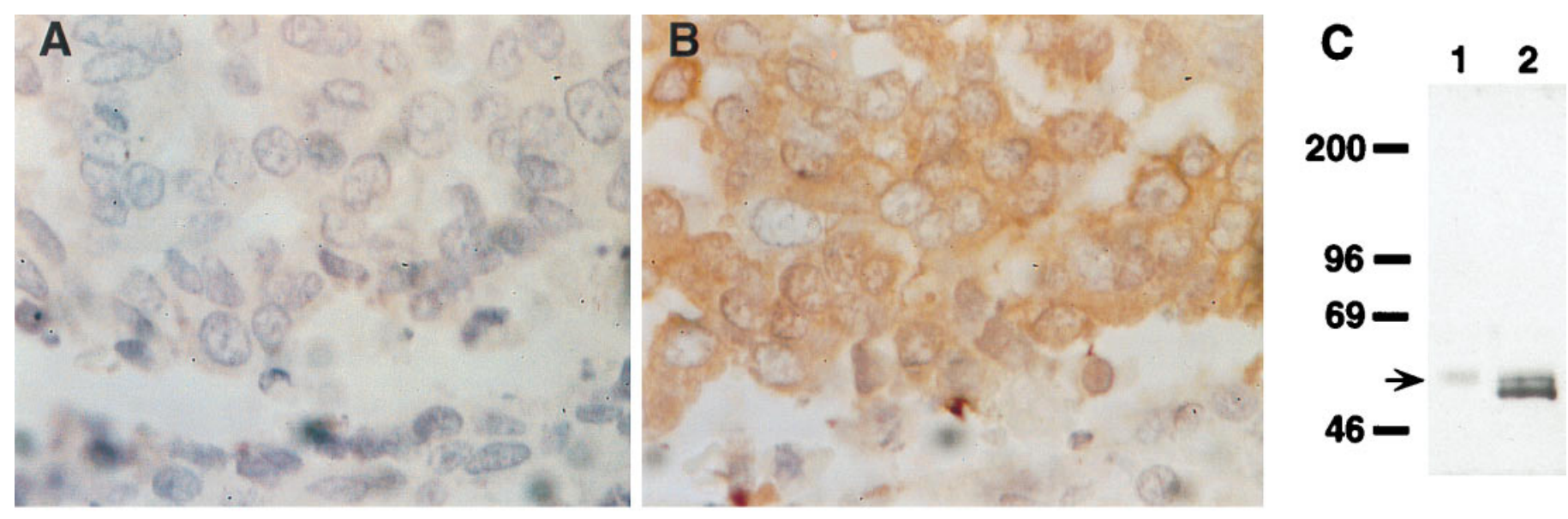

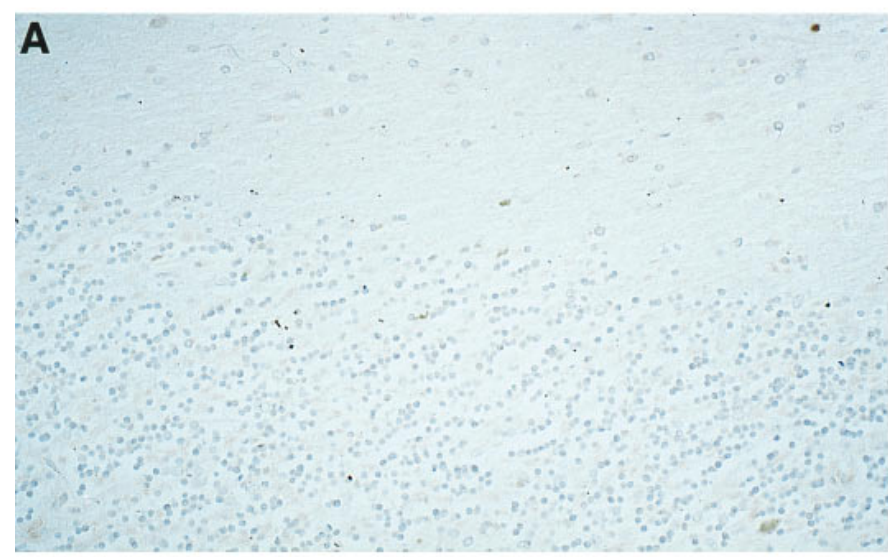

B

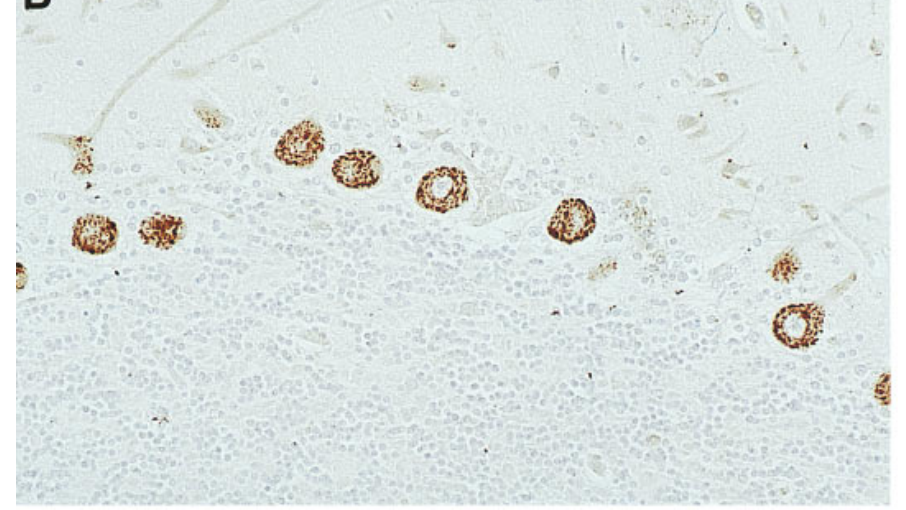

\section{cdr2 mRNA is expressed widely in adult mouse tissues, but the protein is restricted to the brain and testis}

To determine whether cdr2 gene expression was limited to the nervous system, we performed Northern blot analysis using a cdr2-specific cDNA probe. A single cdr2 transcript of $2.8 \mathrm{~kb}$ was detected in eight of nine tissues examined; it was most abundant in testis and spleen and was not detectable in liver (Fig. 5A). This result was confirmed by hybridization with a probe from a different region of the cdr2 gene (data not shown) and by RT-PCR analysis of mouse cerebellum, spleen, heart, and testis RNA (Fig. $5 B$ and data not shown). The cdr2 primer pair used for PCR amplification flanks the region encoding the PCD epitope, suggesting that this region of the cdr2 transcript is the same in each tissue.
Figure 2. Above. Immunoreactivity of PCD ovarian tumors with PCD antisera. Serial sections of a paraffin-embedded PCD ovarian tumor (tumor 2 from Fig. 1) stained with either biotinylated normal human serum $(A)$ or biotinylated PCD antisera $(B)$. PCD antisera displays a characteristic cytoplasmic reactivity in the tumor tissue and not in the surrounding connective tissue seen in the bottom of the photomicrograph. $C$, Detection of the PCD ovarian tumor antigen by Western blot. PCD antisera was immunoreactive with a protein of $M_{\mathrm{r}} 56 \mathrm{kDa}$ (arrowhead) present in both human Purkinje (lane 1) and PCD tumor (lane 2) protein extracts. The lower reactive band in the tumor extract is $\mathrm{IgG}$, determined by probing the same blot with the anti-human IgG secondary antibody alone (data not shown).

Figure 3. Left. Immunohistochemical analysis of normal or PCD cerebellar sections. $A$, Paraffin section of the cerebellum of a PCD patient (corresponding to tumor 3 in Fig. 1) showing complete lack of reactivity with biotinylated PCD antiserum and the absence of Purkinje neurons. $B$, Paraffin section of the cerebellum of a neurologically normal patient demonstrating reactivity of Purkinje cell cytoplasm with PCD antiserum.

To investigate the expression pattern of the PCD antigen, Western blot analysis using affinity-purified PCD antisera was performed on the same battery of adult mouse tissues used for Northern blot analysis. Interestingly, a single band of $M_{\mathrm{r}}=56$ $\mathrm{kDa}$ was detected in cerebellum and testis but not in other tissues (Fig. 6A). On a longer exposure, a faint band was also detected in the cerebral cortex (data not shown). The blot was stripped of antibody and reprobed with a monoclonal antibody to $\beta$-tubulin (Fig. $6 A$ ), demonstrating that equivalent amounts of protein were loaded in each lane. To confirm the identity of the immunoreactive species in brain and testis, we performed 2-D gel electrophoretic analysis. Figure $6 B$ shows that the protein recognized by PCD antisera in cerebellum (top panel) and testis (bottom panel) exactly comigrate by both their molecular weights and isoelectric points ( $\mathrm{pI})$. The protein(s) runs 
ttgggccgggcagcaggcgtgaggagccggctcccggegccacceggggcgcgctcgctagggcgccggcct ttgggcggcgcgggatagcggcgagagctgctgcgggacctgcgtgtccgcccagggtggctctggetgag ggcggcgacatgctggcagataacctagtggaggagttcgagatggaggatgagccgtggtacgaccaccgg

1

gacctccagcaagatctccagcttgctgctgaacttggaaagacgctactggatcggaacacagagttggaa 288

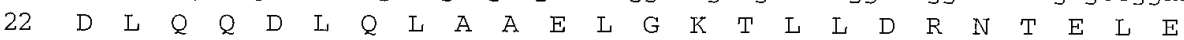
gattctcttcagcagatgtacacaaccaatcaggagcagttacaggaaatcgagtacctgaccaagcaggtg

$\begin{array}{lllllllllllllllllllllllll}46 & \mathrm{D} & \mathrm{S} & \underline{L} & Q & Q & M & Y & T & T & N & Q & E & Q & L & Q & E & I & E & Y & L & T & K & Q & V\end{array}$ gagcttctacggcaaatgaatgagcagcatgcgaaagtttatgagcagttagatgtcacagcaagagaactg 432

$\begin{array}{llllllllllllllllllllllllll}70 & E & L & L & R & Q & M & N & E & Q & H & A & K & V & Y & E & Q & L & D & V & T & A & R & E & L\end{array}$ gaagaaaccaaccagaagctagttgctgagagcaaggcctcacagcagaaaatcctcagcctgacagaaaca 504

$\begin{array}{llllllllllllllllllllllllll}94 & \mathrm{E} & \mathrm{E} & \mathrm{T} & \mathrm{N} & \mathrm{Q} & \mathrm{K} & \mathrm{L} & \mathrm{V} & \mathrm{A} & \mathrm{E} & \mathrm{S} & \mathrm{K} & \mathrm{A} & \mathrm{S} & \mathrm{Q} & \mathrm{Q} & \mathrm{K} & \mathrm{I} & \mathrm{L} & \mathrm{S} & \mathrm{L} & \mathrm{T} & \mathrm{E} & \mathrm{T}\end{array}$ attgaatgcctgcaaaccaacattgatcacctgcagagccaagtggaggagctgaagtcttccagccaagga 576

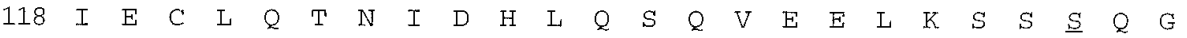
agagggaggcagaaggcatgtgaccaggagaaaccagcacccagcttctcctgtctgaaagagctgtatgac 648

$\begin{array}{lllllllllllllllllllllllll}142 & \mathrm{R} & \underline{G} & \underline{\mathrm{R}} & Q & \underline{\mathrm{K}} & \underline{A} & \mathrm{C} & \mathrm{D} & Q & \mathrm{E} & \mathrm{K} & \mathrm{P} & \mathrm{A} & \mathrm{P} & \mathrm{S} & \mathrm{F} & \underline{\mathrm{S}} & \mathrm{C} & \mathrm{L} & \mathrm{K} & \mathrm{E} & \mathrm{L} & \mathrm{Y} & \mathrm{D}\end{array}$ ctccgccaacactttgtgtatgaccacgtgttcgctgagaagatcacttccttgcagagccaacagagccet 720

$\begin{array}{lllllllllllllllllllllllll}166 & L & R & Q & H & F & V & Y & D & H & V & F & A & E & K & I & T & S & L & Q & \underline{S} & Q & 9 & S & P\end{array}$ gatgaagaagaaa.tgagcacctgaaaaaggcagtgacgatgttgcaggcccagctaagtctagagaggaag

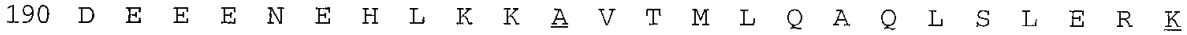
aagcgagtgagcgtggaggcagagtataaagtggtgctgaaggagaacagtgagctggagcagcagctgggg 864

$\begin{array}{lllllllllllllllllllllllll}214 & K & R & V & \underline{S} & \underline{V} & E & \underline{A} & E & Y & \underline{K} & \underline{V} & V & L & K & E & N & S & E & L & E & Q & Q & L & G\end{array}$ gccacagatgcctaccgagcccgggccetggagttggaggcagaggtggctgagatgcggcagatgctgcag 936

$\begin{array}{lllllllllllllllllllllllll}238 & A & T & D & A & Y & R & A & R & A & L & E & L & E & A & E & V & A & E & M & R & Q & M & L & Q\end{array}$ gcagagcatccttttgtgaatggtgtggagaagctggtgcccgactctctgtttgttcctttcaaggagcct

$\begin{array}{lllllllllllllllllllllllll}262 & \underline{A} & E & H & P & F & V & N & G & V & E & K & L & V & P & D & S & L & F & V & P & F & K & E & P\end{array}$ agccagagtctgctggaggaaatgttcctggctgctccagaagcacctagaaaaccactcaaacgaagcagc

$\begin{array}{lllllllllllllllllllllllll}286 & S & Q & S & L & L & E & E & M & F & L & \underline{A} & \underline{A} & P & E & \underline{A} & \underline{P} & R & K & P & L & K & R & S & S\end{array}$ agtgagacggcgctcagcagtttggcaggggatgacatcgtgaaggaccatgaggacacttgcatcaggagg 1152

$\begin{array}{llllllllllllllllllllllllllllllllll}310 & S & E & T & \underline{A} & L & S & S & L & A & G & \underline{D} & D & I & V & K & \underline{D} & H & E & \underline{D} & T & C & I & R & R\end{array}$ gctaaggctgtgaagcagaggggcatctcccttctgcatgaagtggacactcagtacagtgccctgaaagtg

$\begin{array}{lllllllllllllllllllllllll}334 & A & K & A & V & K & Q & R & G & I & S & L & L & H & E & V & D & T & Q & Y & S & A & L & K & V\end{array}$ aagtatgaagagctactgaagaagtgccacgaggagcaggactcactgtcacacaaggctgtgcagacctct

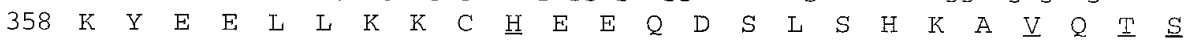
agactactgactagggacctgacaggactggtcacgcagtctgaggcgggggccagtggctgggaacccacc

$\begin{array}{lllllllllllllllllllllllll}382 & \underline{R} & \underline{L} & \underline{L} & \underline{T} & \underline{R} & D & \underline{L} & \underline{T} & \underline{G} & \underline{L} & \underline{V} & \underline{T} & Q & S & E & \underline{A} & \underline{G} & A & S & G & W & E & \underline{P} & \underline{T}\end{array}$ cctgtaagcccagagtccatcagttcccccaccactacacctccagaatacaaagcactatttaaggagata

$\begin{array}{lllllllllllllllllllllllll}406 & P & V & \underline{S} & P & E & \underline{S} & \underline{I} & S & S & P & \underline{T} & T & T & P & P & E & Y & K & A & L & F & K & E & I\end{array}$ tttagttgcatcaagaaaacaaagcaggaaatagatgaacagagaacaaaatacccttctctctcctcttac 1512

$\begin{array}{llllllllllllllllllllllllllllllll}430 & F & S & C & I & K & K & T & K & Q & E & I & D & E & Q & R & T & K & Y & \underline{P} & S & L & S & S & \underline{Y}\end{array}$ tcgtactgagactccagttgtaactgcttgttttcgctcacttgcctccengttcagacatgtaagtgcagt 454 S Y *

ctccaaagcttgacgttgctaatgacacctgcctcgttgctttgcttagttggcaaaagcaggaaaagaggt gacagagaatgttgactccaaggtccctaggaaatctcacgatacactggccgctggttggtacactgattt ccaggaaaagcccagaagcagtagagggagagccatgtacttgggagtaggctgaagtacctaacagtgta gggtaaagaacagaattggaacagaactaaggctgttgctttcatagcatctcagactacttggaactccaa ggactgcctaactaaagtactttcacaaacactaacattcagaaggatgttgagaaagcaagatctaatctg aaatggatgacattaacaagctccttaagcccctgaagttttattgcatctgctagcacttgaatgctgact gacaggcagatcctgatatatccaaattcgaattaataccatttgaaatggnaagtcttnttaacgcctgtt tgtatgcccagcattcagctgttttactcaaagctaggcatgtcatagtaattgtctttcagatggaaact agagaactctcctaggtgtgatctgcactggccacttggcaggcacaagctgcttccttcccctcaggtctt aacccttccagacctgcagcgattcctgtcgactcccttacacagtattgatcttctgactgtggaaacca accttcctctcactttcacacctttaatttaaatctatttaagagaaccatggttctgattgttgtgtatat ttttctaaaggctgaataaagctatctatgaatgtgaaaaaaaaaaaaaaaaaa

72

144

216

Figure 4. Nucleotide and predicted amino acid sequence of the adult mouse brain cdr 2 cDNA. Amino acids are numbered on the left and the nucleotides on the right. The in-frame stop codon upstream of the presumptive initiating methionine and a polyadenylation signal are underlined. The translational stop codon is indicated with an asterisk. The 455 amino acid protein of predicted $\mathrm{M}_{r}=52 \mathrm{kDa}$ is $87 \%$ identical to the human sequence. The amino acids that are not conserved are underlined.

as a broad band with a pI of 6.1-6.4, consistent with previous 2-D gel analysis of human Purkinje cell lysate (Cunningham et al., 1986). This migration pattern in the dimension of isoelectric focusing could be attributable to post-translational or chemical modifications and may also explain the difference between the observed $\mathrm{pI}$ and the predicted pI of 4.76 .
There are several potential explanations for the discrepancy between the tissue distribution of the cdr2 message and the protein detected by the PCD antisera. In tissues other than brain and testis, the PCD antigen may not be recognized by the Yo antibody as a result of alternative processing of the primary transcript, differential post-translational modification of the pro- 
A.

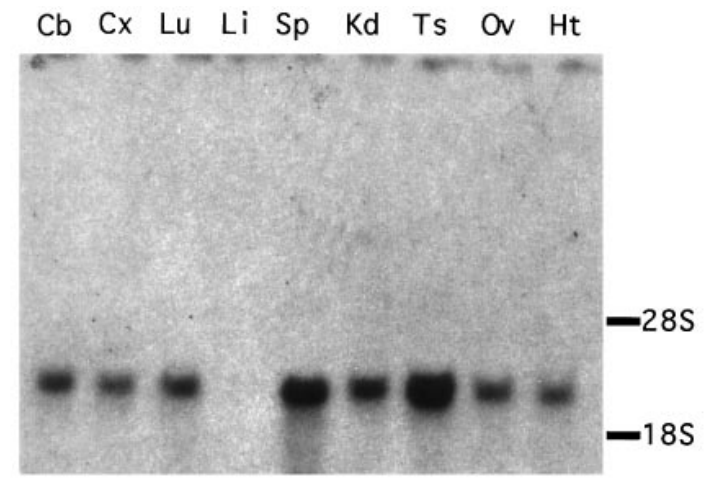

GAPDH

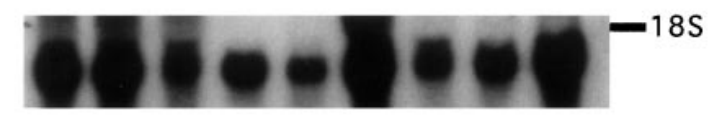

B.

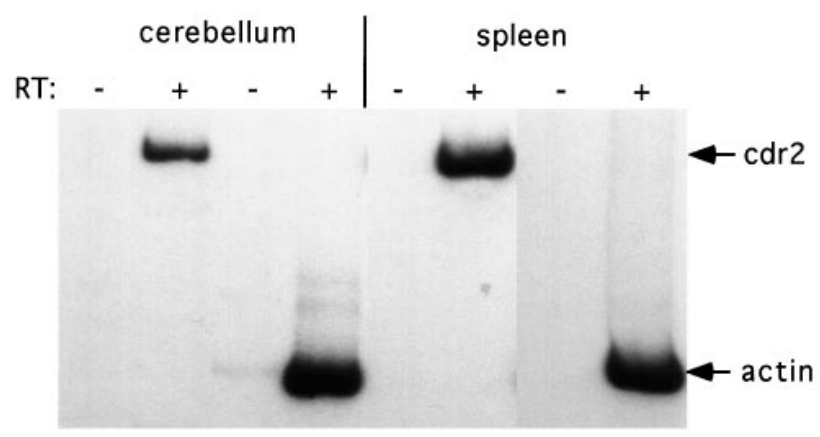

Figure 5. Expression of the cdr2 mRNA in adult mouse tissues. $A, \mathrm{~A}$ Northern blot of total RNA prepared from the indicated tissues was hybridized with a ${ }^{32} \mathrm{P}$-labeled cDNA probe made from the $3^{\prime}$-UTR of mouse cdr2 (top panel). The bottom panel shows hybridization of a GAPDH probe to the same blot as a control for loading of RNA. The mouse tissues used in the analysis were cerebellum $(\mathrm{Cb})$, cerebral cortex $(C x)$, heart $(H t)$, lung $(L u)$, liver $(L i)$, kidney $(K d)$ spleen $(S p)$, ovary $(O v)$, and testis $(T s)$. The relative positions of $28 \mathrm{~S}(5.1 \mathrm{~kb})$ and $18 \mathrm{~S}(2.0 \mathrm{~kb})$ rRNA are shown. A single cdr2 transcript of $2.8 \mathrm{~kb}$ was detected in all tissues tested, with the exception of the liver. $B$, RT-PCR analysis of cdr2 expression in cerebellum versus spleen RNA was performed, as described in Figure 1, using primers flanking the PCD epitope or $\beta$-actin primers. The cdr2 transcript was also detected in heart and testis by this assay (data not shown).

tein, or regulation at the level of translation. To test for the first of these possibilities, we cloned cdr 2 cDNA from spleen. Mouse spleen was chosen, because it represents a tissue in which the cdr2 mRNA was abundant, whereas the protein was undetectable. Two overlapping clones, one nearly full-length, were isolated and found to be identical to the brain cDNA sequence throughout the coding region and UTR. These results suggest that the apparent differences in detectable cdr2 protein in brain and spleen cannot be accounted for by alternatively processed cdr 2 mRNAs.

To address the possibility that the detection of cdr2 may be affected by tissue-specific post-translational modifications or protein stability, we transfected a non-neuronal cell line with an expression vector containing the full cdr2 open reading frame without UTR sequences. The transfected cdr2 plasmid yielded abundant immunoreactive protein in NIH3T3 cells, suggesting that the protein was stable and the epitope was not masked in this fibroblast cell line (data not shown).

\section{cdr2 expression is also regulated at the level of transcription}

To extend our cdr2 expression data, the tissue distribution of cdr2 mRNA and protein was compared by in situ hybridization and immunohistochemistry. A specific in situ hybridization probe was generated from the mouse cdr2 $3^{\prime}$-UTR, and the expression in mouse tissues was compared with the pattern of immunoreactivity seen with affinity-purified or native PCD serum. Both sagittal and coronal sections of adult mouse brain showed a pattern of cdr2 mRNA expression that corresponded precisely to the pattern of immunoreactivity. Abundant cdr2 mRNA and PCD antigen was detected specifically in the cerebellar Purkinje cells, in neurons of the deep cerebellar nuclei, and in brainstem (Fig. 7A,B). cdr2 mRNA and protein were absent from hippocampus, basal ganglia, and neocortex, with the exception of scattered immunoreactive cortical neurons (data not shown).

Outside the nervous system, there was no correlation between cdr2 in situ hybridization and immunohistochemistry except in testis. In sections of adult spleen, the cdr2 mRNA was readily detected, where it was found to be restricted to the splenic cortex (an area rich in lymphocytes) but absent from the red pulp (Fig. $7 C)$. In contrast, there was no detectable cdr 2 immunoreactivity in either the splenic cortex or the pulp (Fig. 7D). Similarly, no immunoreactivity could be detected in any other non-neuronal tissue examined except testis. Immunohistochemical staining of testis revealed that cdr2 cytoplasmic reactivity was restricted to the outermost cell layer of the seminiferous tubules (Fig. $7 F$ ). By their relative position in the tubules and by morphological criteria, these cells appear to be spermatogonia, the least-differentiated type in the germ cell lineage. In situ hybridization of testis revealed that cdr $2 \mathrm{mRNA}$ is abundantly expressed in spermatogonia and could be detected to a lesser degree in early differentiating spermatocytes (Fig. $7 E$ ). Taken together, these data demonstrate an uncoupling of cdr2 mRNA and protein expression, suggesting that a post-transcriptional mechanism restricts cdr2 protein expression to spermatogonia and a subset of neurons.

\section{DISCUSSION}

\section{The onconeural antigen cdr2}

Three genes encoding putative PCD antigens have been identified by expression library screening with PCD antisera (Dropcho et al., 1987; Fathallah-Shaykh et al., 1991; Sakai et al., 1991), but which of these encode proteins that might be relevant to $\mathrm{PCD}$ in vivo has been uncertain. Western blot analysis of PCD tumor tissue probed with PCD antisera previously identified immunoreactive species that might correspond in size to either the cdr2 or cdr3 gene products (Furneaux et al., 1990). Moreover, the cdr2 and cdr3 genes encode proteins that share a common epitope (the leucine zipper domain). We have performed RT-PCR analysis of three PCD-associated ovarian tumors and found that in each of these tumors, the only PCD-related gene to be expressed is $\operatorname{cdr} 2$, and we conclude that the cdr2 protein is the PCD tumor antigen.

Based on RNA analysis and immunohistochemical studies (Sakai et al., 1991; Tomimoto et al., 1993), it had been thought previously that the PCD antigen cdr2 might be expressed outside the nervous system, generating uncertainty regarding its role as an onconeural antigen. We have demonstrated that the expression of the PCD antigen is normally restricted to neurons and testis, sites exhibiting the characteristics of immune privilege. Twodimensional gel analysis confirms that the immunoreactive species evident on Western blot analysis is the same protein in both 
Figure 6. Detection of the PCD antigen in adult mouse tissues. $A$, Affinitypurified PCD antisera was used to probe a Western blot of the indicated protein extracts (top panel, abbreviated as in Fig. 3). The blot was stripped of antibody and reprobed with a monoclonal antibody to $\beta$-tubulin as a proteinloading and transfer control (bottom panel); the lower band is mouse Ig heavy chain. The cdr2 affinity-purified antibody recognizes a $\mathrm{M}_{r} 56 \mathrm{kDa}$ antigen only in brain and testis. $B$, Twodimensional gel electrophoresis of protein extracts from cerebellum $(i)$ and testis (ii). Proteins were resolved by their isoelectric points in the horizontal direction (the direction and end points of the $\mathrm{pH}$ gradient are shown above) and by their molecular weights in the vertical direction. The major species detected by PCD antisera in cerebellum and testis comigrate in both dimensions.

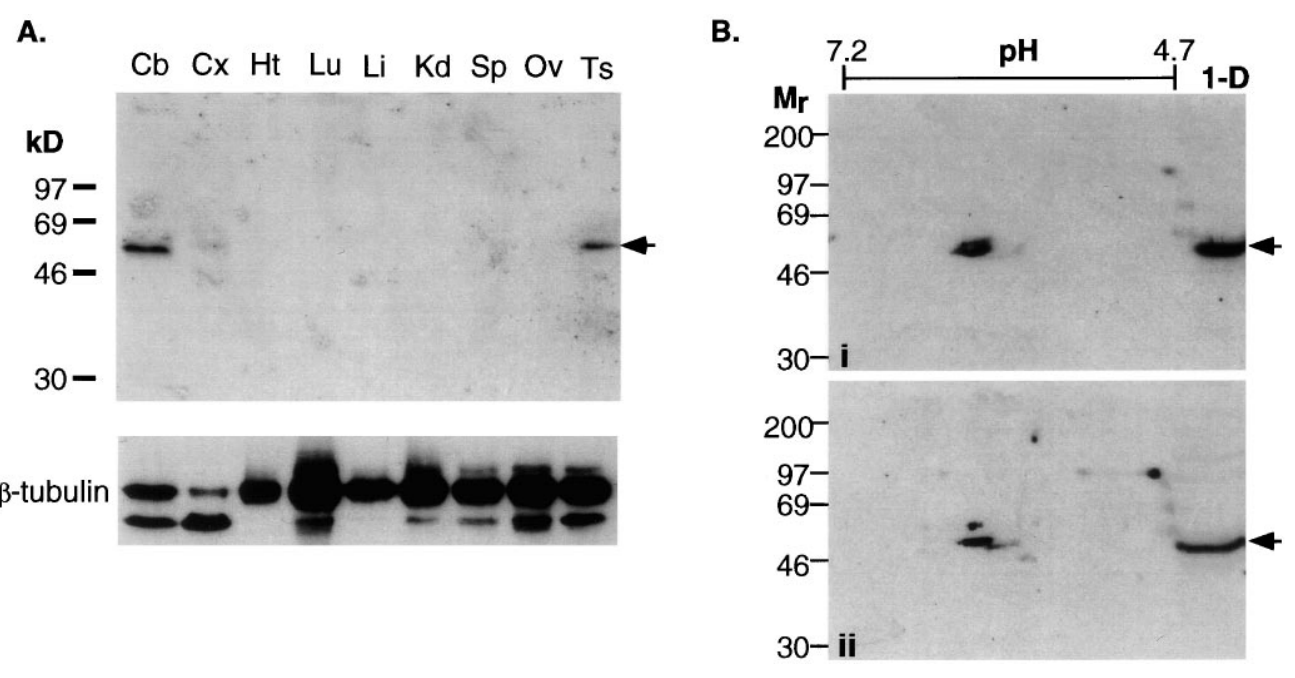

tissues. This expression pattern is consistent with the proposed role of cdr2 as an onconeural antigen.

The expression of previously characterized onconeural antigens and some autoimmune antigens has been found to be very tightly restricted to neurons. The Nova and $\mathrm{Hu}$ onconeural antigens are RNA-binding proteins expressed exclusively in neurons both early in embryogenesis and in adults (Szabo et al., 1991; Dalmau et al., 1992; Buckanovich et al., 1993, 1995). Similarly, the autoimmune cerebellar degeneration antigen $\beta$-NAP is a neuron-specific vesicle coat protein (Newman et al., 1995), and the stiff-man syndrome antigens GAD (Solimena et al., 1988) and amphiphysin (DeCamilli et al., 1993) are nerve terminal vesicle-associated proteins. Our findings are thus concordant with the strict regulation of onconeural antigen expression but indicate that their expression may extend to immune-privileged cells outside the nervous system.

The phenomenon of immune privilege, traditionally described as the prolonged survival of allogeneic or xenogeneic grafts, has been studied most extensively in the brain, eye, and testis (Streilein, 1993). Immune privilege in the nervous system has both a physical and a molecular component, defined by the blood-brain barrier and the lack of detectable MHC class I or II antigens, respectively (Bradbury, 1984; Pollack and Lund, 1990). There are also active mechanisms by which immune-privileged tissues evade immune surveillance. For example, cells in the anterior chamber of the eye and the testis express fas ligand as a means of inducing apoptosis of autoreactive immune cells (Bellgrau et al., 1995; for comments, see Griffith et al., 1995). Although these studies have examined the immune response to foreign antigens expressed within immune-privileged tissues, they imply that proteins normally restricted in their expression to such sites may be highly immunogenic when ectopically expressed.

In PND, it is believed that sequestration of onconeural antigens from immune surveillance in the brain results in lack of immune tolerance to these proteins when they are ectopically expressed in tumor cells. We have shown that cdr2 is the only cdr gene expressed in ovarian tumors from PCD patients, and thus appears to be the inciting onconeural antigen. Ectopic expression of cdr2 is associated with a robust immune response to the antigen. The presence of a specific high-titer autoantibody and limited tumor growth in PCD patients provide clinical evidence for an active anti-tumor immune response (Anderson et al., 1988b; Peterson et al., 1992) and suggest that the cdr2 protein may act as a bona fide tumor antigen.

It remains uncertain how a systemic immune response to ectopically expressed cdr2 protein becomes competent to recognize the antigen within the brain. However, it does appear that the autoimmune response within the nervous system in PCD is likely to be directed against cdr2. Pathological examination of PCD brains reveals degeneration of the same neurons in which cdr2 is expressed, most prominently Purkinje neurons of the cerebellum (Fig. 3) (Peterson et al., 1992; Verschuuren et al., 1996). Taken together, these observations suggest that autoimmunity to cdr2 in PCD proceeds in two steps. First, a naive immune system is naturally competent to recognize cdr2 in PCD tumors. A second unidentified event, perhaps involving cytokines or a change in the nature of the cellular immune response, allows the immune privilege of the brain to be breached, culminating in autoimmune neurological disease.

\section{Regulation of the cdr2 antigen at a post-transcriptional level}

We have clarified the nature of PCD by definitively identifying cdr2 as the neuronal gene that is ectopically expressed in PCD tumors. Given the significance of such onconeural genes to tumor biology and neurobiology (for review, see Darnell, 1996), this observation focuses attention on studies of the regulation of cdr2 expression. We have defined the tissue-specific expression pattern of the cdr2 antigen and found that it is regulated at a posttranscriptional level. A single cdr2 transcript is detected in nearly all tissues, whereas the PCD antigen is expressed specifically in brain and testis. Sequence analysis of both brain and spleen cdr2 cDNAs reveals that these mRNAs are identical, indicating that there is a tissue-specific regulatory mechanism responsible for restricting expression of the cdr2 protein that operates after mRNA processing.

The discrepancy between the distribution of cdr2 message and protein suggests several possible underlying mechanisms. Perhaps the most likely is that translational control regulates the expression of cdr2. Such a mechanism might relate either to an induction of translation specifically in brain and testis or a repression of translation in other tissues. There are several examples of tissueor cell type-specific regulation of translation, including the testis proenkephalin mRNA, S-adenosylmethionine decarboxylase and 

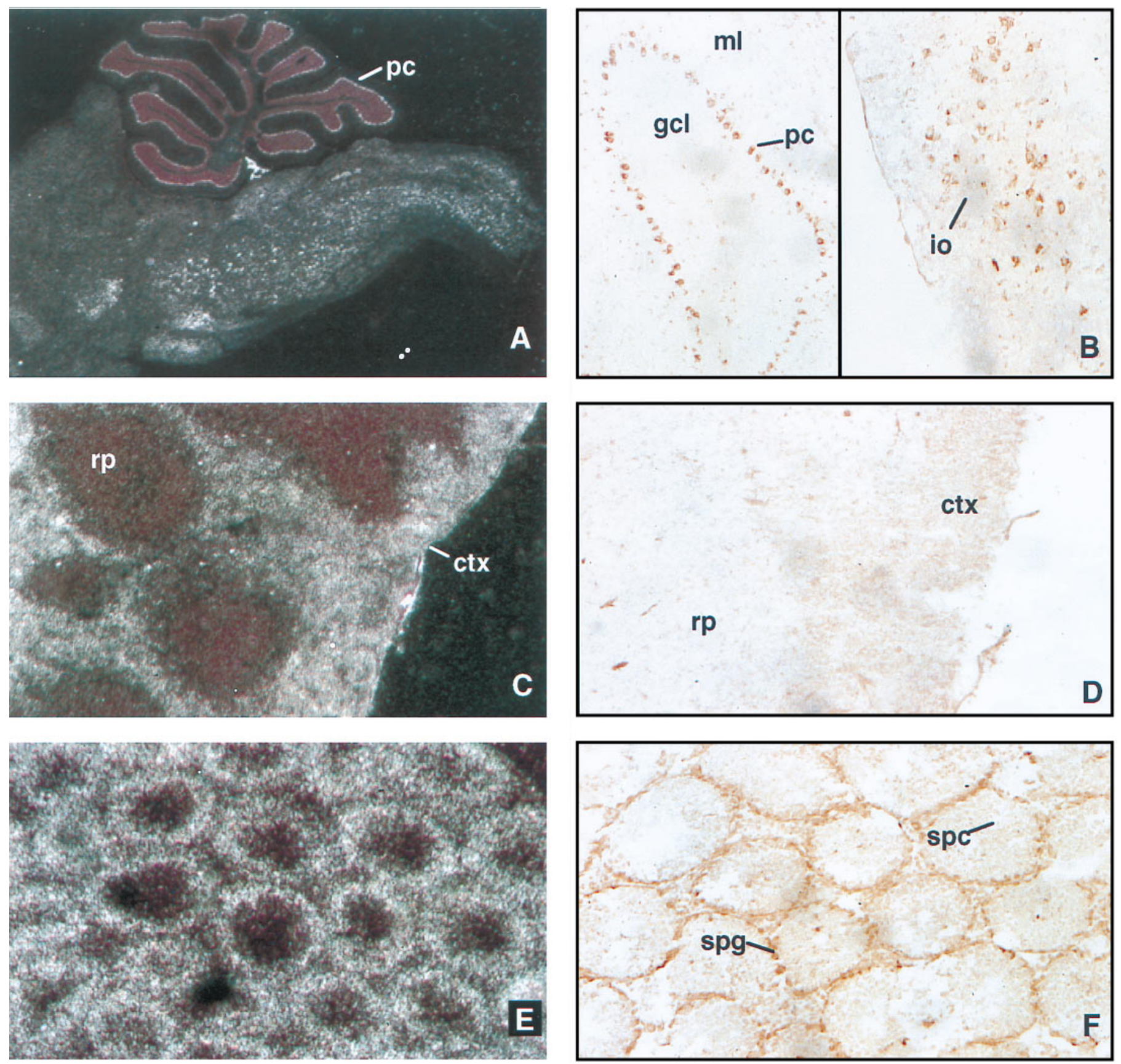

Figure 7. Analysis of cdr2 expression by in situ hybridization $(A, C, E)$ and immunohistochemistry $(B, D, F)$. Sections of adult mouse brain $(A, B)$, spleen $(C, D)$, and testis $(E, F)$ were hybridized with a ${ }^{33} \mathrm{P}$-labeled $\mathrm{cdr} 2$ riboprobe or reacted with either affinity-purified or native PCD antisera. Dark-field photomicrographs reveal that the cdr2 mRNA is detected in cerebellar Purkinje neurons, many brainstem neurons $(A)$, splenic cortical cells $(C)$, and cells of the outermost layers of the seminiferous tubules in the testis $(E)$. There was no clear pattern of expression in the cerebral cortex, and no hybridization was observed with cdr2 sense probes in any of the tissues examined (data not shown). Immunoreactivity with affinity-purified or native PCD antisera was detected in cerebellar Purkinje neurons, brainstem neurons $(B$, left and right panels, respectively), scattered neurons of the cerebral cortex (data not shown), and spermatogonia in the testis $(F)$. Immunoreactivity was absent in spleen $(D)$, which shows only background reactivity when compared with a normal human serum control (data not shown). $p c$, Purkinje cells; $g c l$, granule cell layer; $m l$, molecular layer; io, inferior olive; $r p$, red pulp; $c t x$, cortex; spg, spermatogonia; $s p c$, spermatocytes.

the transcription factor BTEB (Hill and Morris, 1992; Rao and Howells, 1993; Imataka et al., 1994). Interestingly, the expression of BTEB closely resembles that of cdr2, in that the mRNA is detected in many tissues, whereas the protein is found only in brain and testis.

Most cases of translational regulation involve sequence elements in the $5^{\prime}$ or $3^{\prime}$-UTRs of the mRNA. These elements may form stable secondary structures that either directly impede the translation initiation complex or may act as binding sites for trans-acting regulatory factors (Melefors and Hentze, 1993). In addition to complex secondary structure, many tightly regulated genes contain multiple upstream AUG codons (uAUGs), often present in long 5'-UTRs, that serve to decrease translational efficiency (Kozak, 1989, 1991a,b; Geballe and Morris, 1994). Both 
S-adenosylmethionine decarboxylase and BTEB require the presence of such uAUGs in their 5'-UTRs for inhibition of translation. The $5^{\prime}$-UTR of human and mouse cdr 2 cDNAs have $\sim 80 \%$ $\mathrm{G}+\mathrm{C}$ content in the $135 \mathrm{bp}$ immediately upstream of the initiating methionine, predicting stable secondary structure. In addition, there are specific sequence elements within the cdr2 5 '-UTR that are conserved across species.

Several alternate explanations for the discrepancy between the expression of cdr2 mRNA and protein may be considered. The cdr2 protein could be translated constitutively but selectively unstable because of a tissue-specific degradation mechanism. Although there are examples of proteins targeted for degradation in response to specific signals, there is little precedence for such a mechanism regionally restricting protein expression. Moreover, our observation that the cdr2 protein is able to be expressed at high levels when transfected into non-neuronal cells (data not shown) suggests that the stability of the protein is not likely to be dependent on tissue-specific factors.

It is also possible that our results reflect tissue-specific differences in post-translational modifications affecting the PCD epitope, such that the protein is only immunoreactive in brain and testis. Notably, the cdr2 leucine zipper harbors several potential phosphorylation sites. However, we have found that bacterially expressed cdr 2 fusion protein, full-length cdr2 translated in reticulocyte lysate, and cdr2 protein expressed in a transfected fibroblast cell line are all readily detected by PCD antisera (Corradi and Darnell, unpublished observations). Therefore, it is unlikely that a neuron-specific post-translational modification, or lack thereof, is a significant factor in recognition of the cdr2 epitope. A more direct approach to address this question would be to generate antibodies against other epitopes of the cdr2 protein to examine expression of the antigen.

\section{REFERENCES}

Altermatt HJ, Rodriguez M, Scheithauer BW, Lennon VA (1991) Paraneoplastic anti-Purkinje and type I anti-neuronal nuclear autoantibodies bind selectively to central, peripheral, and autonomic nervous system cells. Lab Invest 65:412-420.

Anderson NE, Rosenblum MK, Graus F, Wiley R, Posner JB (1988a) Autoantibodies in paraneoplastic syndromes associated with small-cell lung cancer. Neurology 38:1391-1398.

Anderson NE, Rosenblum MK, Posner JB (1988b) Paraneoplastic cerebellar degeneration: clinical-immunological correlations. Ann Neurol 24:559-567.

Bellgrau D, Gold D, Selawry H, Moore J, Franzusoff A, Duke RC (1995) A role for CD95 ligand in preventing graft rejection. Nature 377:630-632.

Bradbury MWB (1984) The structure and function of the blood-brainbarrier. Fed Proc 43:186-190.

Buckanovich R, Posner JB, Darnell RB (1993) Nova, the paraneoplastic $\mathrm{Ri}$ antigen, is homologous to an RNA-binding protein and is specifically expressed in the developing motor system. Neuron 11:657-672.

Buckanovich RJ, Yang YY, Darnell RB (1996) The onconeural antigen Nova-1 is a neuron-specific RNA binding protein, the activity of which is inhibited by paraneoplastic antibodies. J Neurosci 16:1114-1122.

Chomcynski P, Sacchi N (1987) Single-step method of RNA isolation by acid guanidinium thiocyanate-phenol-chloroform extraction. Anal Biochem 162:156-159.

Cunningham J, Graus F, Anderson N, Posner JB (1986) Partial characterization of the Purkinje cell antigens in paraneoplastic cerebellar degeneration. Neurology 36:1163-1168.

Dalmau J, Furneaux HM, Gralla RJ, Kris MG, Posner JB (1990) Detection of the anti-Hu antibody in the serum of patients with small cell lung cancer-a quantitative Western blot analysis. Ann Neurol 27:544-552.

Dalmau J, Furneaux HM, Cordon-Cardo C, Posner JB (1992) The expression of the $\mathrm{Hu}$ (paraneoplastic encephalomyelitis/sensory neu- ronopathy) antigen in human normal and tumor tissues. Am J Pathol 141:881-886.

Darnell RB (1996) Onconeural antigens and the paraneoplastic neurologic disorders: at the intersection of cancer, immunity, and the brain. Proc Natl Acad Sci USA 93:4529-4536.

Darnell RB, DeAngelis LM (1993) Regression of small-cell lung carcinoma in patients with paraneoplastic neuronal antibodies. Lancet 341:21-22.

DeCamilli P, Thomas A, Cofiell R, Folli F, Lichte B, Piccolo G, Meinck HM, Austoni M, Fassetta G, Bottazzo G, Bates D, Cartlidge N, Solimena M, Kilimann MW (1993) The synaptic vesicle-associated protein amphiphysin is the $128 \mathrm{kDa}$ autoantigen of Stiff- Man syndrome with breast cancer. J Exp Med 178:2219-2223.

Dropcho EJ, Chen YT, Posner JB, Old LJ (1987) Cloning of a brain protein identified by autoantibodies from a patient with paraneoplastic cerebellar degeneration. Proc Natl Acad Sci USA 84:4552-4556.

Fathallah-Shaykh H, Wolf S, Wong E, Posner JB, Furneaux HM (1991) Cloning of a leucine-zipper protein recognized by the sera of patients with antibody-associated paraneoplastic cerebellar degeneration. Proc Natl Acad Sci USA 88:3451-3454.

Furneaux H, Rosenblum M, Dalmau J, Wong E, Woodruff P, Graus F, Posner J (1990) Selective expression of Purkinje-cell antigens in tumor tissue from patients with paraneoplastic cerebellar degeneration. N Engl J Med 322:1844-1851.

Geballe AP, Morris DR (1994) Initiation codons within 5'-leaders of mRNAs as regulators of translation. Trends Biochem Sci 19:159-164.

Griffith TS, Brunner T, Fletcher SM, Green DR, Ferguson TA (1995) Fas ligand-induced apoptosis as a mechanism of immune privilege. Science 270:1189-1192.

Hill JR, Morris DR (1992) Cell-specific translation of S- adenosylmethionine decarboxylase mRNA. Regulation by the $5^{\prime}$ transcript leader. J Biol Chem 267:21886-21893.

Imataka H, Nakayama K, Yasumoto K, Mizuno A, Fujii-Kuriyama Y, Hayami M (1994) Cell-specific translational control of transcription factor BTEB expression. The role of an upstream AUG in the 5'untranslated region. J Biol Chem 269:20668-20673.

Jaeckle KA, Graus F, Houghton A, Cardon-Cardo C, Nielsen SL, Posner JB (1985) Autoimmune response of patients with paraneoplastic cerebellar degeneration to a Purkinje cell cytoplasmic protein antigen. Ann Neurol 18:592-600.

Kozak M (1989) The scanning model for translation: an update. J Cell Biol 108:229-241.

Kozak M (1991a) An analysis of vertebrate mRNA sequences: intimations of translational control. J Cell Biol 115:887-903.

Kozak M (1991b) Structural features in eukaryotic mRNAs that modulate the initiation of translation. J Biol Chem 266:19867-19870.

Luque F, Furneaux H, Ferziger R, Rosenblum M, Wray S, Schold S, Glantz M, Jaeckle K, Biran H, Lesser M, Paulsen W, River M, Posner J (1991) Anti-Ri: an antibody associated with paraneoplastic opsoclonus and breast cancer. Ann Neurol 29:241-251.

Melefors O, Hentze MW (1993) Translational regulation by mRNA/ protein interactions in eukaryotic cells: ferritin and beyond. BioEssays 15:85-90.

Newman LS, McKeever MO, Okano HJ, Darnell RB (1995) $\beta$-NAP, a cerebellar degeneration antigen, is a neuron-specific vesicle coat protein. Cell 82:773-783.

O'Farrell PH (1975) High resolution two-dimensional electrophoresis of proteins. J Biol Chem 250:4007-4021.

Peterson K, Rosenblum MK, Kotanides H, Posner JB (1992) Paraneoplastic cerebellar degeneration. I. A clinical analysis of 55 anti-Yo antibody-positive patients. Neurology 42:1931-1937.

Pollack IF, Lund RD (1990) The blood-brain barrier protects foreign antigens in the brain from immune attack. Exp Neurol 108:114-121.

Posner JB, Furneaux HM (1990) Paraneoplastic syndromes. In: Immunologic mechanisms in neurologic and psychiatric disease, p 187. New York: Raven.

Rao SM, Howells RD (1993) cis-acting elements in the 5'-untranslated region of rat testis proenkephalin mRNA regulate translation of the precursor protein. J Biol Chem 268:22164-22169.

Sakai K, Mitchell DJ, Tsukamoto T, Steinman L (1991) Isolation of a complementary DNA clone encoding an autoantigen recognized by an anti-neuronal cell antibody from a patient with paraneoplastic cerebellar degeneration. Ann Neurol 30:738.

Sakai K, Ogasawara T, Hirose G, Jaeckle KA, Greenlee JE (1993) Anal- 
ysis of autoantibody binding to $52-\mathrm{kd}$ paraneoplastic cerebellar degeneration-associated antigen expressed in recombinant proteins. Ann Neurol 33:373-380.

Sambrook J, Fritsch EF, Maniatis T (1989) Molecular cloning, a laboratory manual. New York: Cold Spring Harbor Laboratory.

Sanger F, Nicklen S, Coulson AR (1977) DNA sequencing with chainterminating inhibitors. Proc Natl Acad Sci USA 74:7463-7467.

Solimena M, Folli F, Denis-Donini S, Comi G, Pozza G, DeCamilli P, Vicari A (1988) Autoantibodies to glutamic acid decarboxylase in a patient with stiff-man syndrome, epilepsy, and type I diabetes mellitus. N Engl J Med 318:1012-1020.

Streilein JW (1993) Immune privilege as the result of local tissue barriers and immunosuppressive microenvironments. Curr Opin Immunol 5:428-432.
Szabo A, Dalmau J, Manley G, Rosenfeld M, Wong E, Henson J, Posner JB, Furneaux HM (1991) HuD, a paraneoplastic encephalomyelitis antigen contains RNA-binding domains and is homologous to Elav and sex lethal. Cell 67:325-333.

Tomimoto H, Brengman JM, Yanagihara T (1993) Paraneoplastic cerebellar degeneration with a circulating antibody against neurons and non-neuronal cells. Acta Neuropathol (Berlin) 86:206-211.

Tsukamoto T, Yamamoto H, Iwasaki Y, Yoshie O, Terunuma H, Suzuki H (1989) Antineural autoantibodies in patients with paraneoplastic cerebellar degeneration. Arch Neurol 46:1225-1229.

Verschuuren J, Chuang L, Rosenblum M, Lieberman F, Pryor A, Posner J, Dalmau J (1996) Inflammatory infiltrates and complete absence of Purkinje cells in anti-Yo-associated paraneoplastic cerebellar degeneration. Acta Neuropathol 91:519-525. 